\title{
Biomedical properties and preparation of iron oxide-dextran nanostructures by MAPLE technique
}

\author{
Carmen Steluta Ciobanu', Simona Liliana Iconaru', Eniko Gyorgy ${ }^{2}$, Mihaela Radu ${ }^{3}$, Marieta Costache ${ }^{3}$, \\ Anca Dinischiotu ${ }^{3}$, Philippe Le Coustumer ${ }^{4}$, Khalid Lafdi ${ }^{5}$ and Daniela Predoi ${ }^{1^{*}}$
}

\begin{abstract}
Background: In this work the chemical structure of dextran-iron oxide thin films was reported. The films were obtained by MAPLE technique from composite targets containing $10 \mathrm{wt}$. \% dextran with 1 and $5 \mathrm{wt} . \%$ iron oxide nanoparticles (IONPs). The IONPs were synthesized by co-precipitation method. A KrF* excimer laser source $(\lambda=$ $248 \mathrm{~nm}, \tau_{\mathrm{FWHM}} \cong 25 \mathrm{~ns}, v=10 \mathrm{~Hz}$ ) was used for the growth of the hybrid, iron oxide NPs-dextran thin films.

Results: Dextran coated iron oxide nanoparticles thin films were indexed into the spinel cubic lattice with a lattice parameter of $8.36 \AA$. The particle sized calculated was estimated at around $7.7 \mathrm{~nm}$. The XPS shows that the binding energy of the Fe $2 p_{3 / 2}$ of two thin films of dextran coated iron oxide is consistent with $\mathrm{Fe}^{3+}$ oxides. The atomic percentage of the $\mathrm{C}, \mathrm{O}$ and $\mathrm{Fe}$ are $66.71,32.76$ and 0.53 for the films deposited from composite targets containing 1 wt.\% maghemite and 64.36, 33.92 and 1.72 respectively for the films deposited from composite targets containing $5 \mathrm{wt} . \%$ maghemite. In the case of cells cultivated on dextran coated $5 \%$ maghemite $\gamma$ - $\mathrm{Fe}_{2} \mathrm{O}_{3}$, the number of cells and the level of F-actin were lower compared to the other two types of thin films and control.

Conclusions: The dextran-iron oxide continuous thin films obtained by MAPLE technique from composite targets containing $10 \mathrm{wt} . \%$ dextran as well as 1 and $5 \mathrm{wt} . \%$ iron oxide nanoparticles synthesized by co-precipitation method presented granular surface morphology. Our data proved a good viability of Hep G2 cells grown on dextran coated maghemite thin films. Also, no changes in cells morphology were noticed under phase contrast microscopy. The data strongly suggest the potential use of iron oxide-dextran nanocomposites as a potential marker for biomedical applications.
\end{abstract}

Keywords: Iron oxide, Polysaccharides, MAPLE, Thin films, HepG2 cells

\section{Background}

Iron oxide nanoparticles and their composites have received increasing attention for their promising biomedical applications [1-7]. The material is highly biocompatible and can be easily conjugated with bioactive molecules. Recently, nanoscale iron oxide nanoparticles have been applied as light scattering labels and luminescent optical markers [1-3] because of their potential applications as contrasting materials for magnetic

\footnotetext{
* Correspondence: dpredoi@gmail.com

${ }^{1}$ National Institute of Materials Physics, P.O. Box MG 07, Bucharest, Magurele, Romania

Full list of author information is available at the end of the article
}

resonance imaging (MRI) [4-7], in vitro cell separation $[8,9]$, targeted drug delivery [10], hyperthermia $[11,12]$, etc.

Nanophase composite materials exhibit physical and chemical properties which differ considerably from bulk materials. The size effect [13] and the surface chemistry [14] play a major role in the biological applications. To control the surface properties of iron oxide nanoparticles, coating is applied with a biocompatible polymer during or after the synthesis process $[15,16]$. To overcome any potential risk of toxicity and high-level accumulation in the target tissue or organ, the iron oxide nanoparticles (IONPs) may be subjected to further functionalization using bioactive molecules [17]. 
Pulsed Laser Deposition (PLD) is a well know method for laser processing of inorganic materials structures and thin films. This technique is however with few exceptions unsuitable for the immobilization of biomaterials, like polymers, biopolymers and proteins $[18,19]$. UV laser organic material interactions can lead to irreversible photochemical transformations of the transferred material. For these reasons, the development of other methods was necessary. One of these methods is called Matrix Assisted Pulsed Laser Evaporation (MAPLE). It provides a gentle mechanism to transfer small and large molecular weight species from condensed phase into the vapor phase. In this technique, the organic and/or nanomaterial are diluted in a volatile non-interacting solvent, with concentration of a few percent (in weight), and frozen at liquid nitrogen temperature. The frozen target is irradiated with a pulsed laser beam, whose energy is principally absorbed by the solvent and converted to thermal energy, allowing the solvent to vaporize and to be evacuated by the vacuum system. The solute material collects on a suitable substrate placed in front of target [20-22]. Since the laser energy is absorbed mainly by volatile solvent matrix, the photochemical decomposition of the organic material can be minimized or even eliminated. The evaporation process is defined by thermodynamic parameters of the volatile solvent and not by the organic material. The deposition is conducted at lower energy densities than in the case of conventional PLD, as with additional precaution to avoid thermal decomposition of organic materials.

First investigations have shown that MAPLE technique offers the possibility to deposit complex materials without significant modifications in their chemical structure and their functional properties if laser parameters are adequately selected regarding the wavelength, fluence and pulse duration. The type of solvent substrate temperature and pressure in the reaction chamber are also important.

In this paper, the physico-chemical and biological properties of polymer nanocomposites thin films containing IONPs in a dextran matrix were investigated. To study the structural and morphological state of the films, X-ray analysis and scanning electron microscopy were used. Adsorption of dextran on the surface of IONPs was investigated by X-ray Photoelectron Spectroscopy (XPS), X-ray diffraction (XRD), Scanning Electron Microscope (SEM) coupled with an Energy Dispersive $\mathrm{X}$-ray detector (EDX), Glow Discharge Optical Emission Spectroscopy, Fourier Transform Infrared (FTIR) Spectroscopy.

\section{Experimental section Materials}

Ferrous chloride tetrahydrate $\left(\mathrm{FeCl}_{2} \cdot 4 \mathrm{H}_{2} \mathrm{O}\right)$, ferric chloride hexahidrate $\left(\mathrm{FeCl}_{3} \cdot 6 \mathrm{H}_{2} \mathrm{O}\right)$, natrium hydroxide
$(\mathrm{NaOH})$, dextran $\mathrm{H}_{(}\left(\mathrm{C}_{6} \mathrm{H}_{10} \mathrm{O}_{5}\right)_{\mathrm{x}} \mathrm{OH}$, ferric nitrate $\left(\mathrm{FeNO}_{3}\right)$, nitric acid $\left(\mathrm{HNO}_{3}\right)$ and chlorhidric acid $(\mathrm{HCl})$ where purchased from Merck. Deionized water was used in the synthesis of nanoparticles, and for rinsing of clusters.

\section{Synthesis of iron oxide ferrofluid}

IONPs were prepared by co-precipitation [23-26]. Ferrous chloride tetrahydrate $\left(\mathrm{FeCl}_{2} \cdot 4 \mathrm{H}_{2} \mathrm{O}\right)$ in $2 \mathrm{M} \mathrm{HCl}$ and ferric chloride hexahydratate $\left(\mathrm{FeCl}_{3} \cdot 6 \mathrm{H}_{2} \mathrm{O}\right)$ were mixed at $100^{0} \mathrm{C}\left(\mathrm{Fe}^{2+} / \mathrm{Fe}^{3+}=1 / 2\right)$. The mixture was dropped into $200 \mathrm{ml}$ of $\mathrm{NaOH}\left(2 \mathrm{~mol} \cdot \mathrm{L}^{-1}\right)$ solution under vigorous stirring for about $30 \mathrm{~min}$. The precipitate of magnetite (black precipitate immediately formed) was converted into $\gamma-\mathrm{Fe}_{2} \mathrm{O}_{3}$ particles by repeated treatment with $\mathrm{HNO}_{3}\left(2 \mathrm{~mol} \cdot \mathrm{L}^{-1}\right)$ and $\mathrm{FeNO}^{3}\left(0.3 \mathrm{~mol} \cdot \mathrm{L}^{-1}\right)$ solutions [27]. The acidic precipitate was isolated by decantation on a magnet, separated by centrifugation $(6000$ $\mathrm{rpm})$, then washed in acetone and dispersed in deionized water at $\mathrm{pH}=2.5$. The final ion concentration was $0.38 \mathrm{~mol} \cdot \mathrm{L}^{-1}$. In a final step, the obtained product was mixed at various ratios with different polymer solutions to obtain iron oxide coated with dextran. For biological investigations, the $\mathrm{pH}$ was adjusted to 7 using aqueous amonia. The iron content of the suspensions was determined by redox-titration [27].

\section{Immobilisation in form of thin films of dextran and dextran coated maghemite nanoparticles}

The UV-MAPLE deposition setup include a vacuum deposition chamber and a UV $\mathrm{KrF}^{*}$ excimer laser (Lambda Physics Coherent, COMPexPro 205 model; $\lambda=$ $248 \mathrm{~nm}, \tau_{\mathrm{FWHM}} \approx 25 \mathrm{~ns}, v=10 \mathrm{~Hz}$ ) [28]. The laser beam was focused onto the target surface trough a 30 cm FD MgF2 cylindrical lens placed outside the reaction chamber. The incident angle between the laser beam and the target was $45^{\circ}$. Before each deposition the $\mathrm{SiO}_{2}$ glass substrate was cleaned with ethanol in ultrasonic bath for $10 \mathrm{~min}$ and then placed inside the deposition chamber parallel with the target at $4 \mathrm{~cm}$ distance. To avoid significant changes in the surface morphology of the target this was rotated during the multipuls laser irradiation with a frequency of $10 \mathrm{~Hz}$.

In our experiments we used solutions consisting of maghemite NPs (0-5 wt. \% concentration), dextran (10 wt.\% concentration), and distilled water as matrix solvent, prepared by a chemical co-precipitation method.

Before each deposition, $5 \mathrm{ml}$ of the obtained solution were dropped in a cooper holder with $3 \mathrm{~cm}$ diameter and $5 \mathrm{~mm}$ height and converted into solid (the future MAPLE target) freezing the solution in liquid nitrogen (77 K). The cryogenic process is induced by immersing the target in liquid nitrogen and/or maintained in direct contact with a device connected through cooper pipes 
at a liquid nitrogen reservoir. In this way, the rapid vaporization of MAPLE target inside the reaction chamber is greatly slowed down.

The irradiation chamber was evacuated down to a residual pressure of $13 \mathrm{~Pa}$. We applied $25 \times 10^{3}$ subsequent laser pulses to deposit each film. The incident laser fluence on the target surface was $0.5 \mathrm{~J} / \mathrm{cm}^{2}$ for each structure.

\section{Characterization methods}

\section{$X$-ray photoelectron spectroscopy (XPS)}

The spectra were measured on a VG ESCA 3 MK II XPS installation using monocromatic $\mathrm{Al} \mathrm{K} \alpha$ irradiation $(1486.7 \mathrm{eV})$. The vacuum in the analyzer chamber was $\mathrm{p}$ $\sim 3 \times 10-8$ torr. The X-rays are emitted by an anti-cathode of $\mathrm{Al}, \mathrm{U}=12.5 \mathrm{kV}$, filament emission current $\mathrm{I}=$ $20 \mathrm{~mA}$, flood gun: $2 \mathrm{~V}$, electron current $\mathrm{I}=0.3 \mathrm{~mA}$, voltage on electron multiplier $\mathrm{U}=2.8 \mathrm{kV}$. The XPS recorded spectrum involved an energy window $\mathrm{w}=20$ $\mathrm{eV}$ with the resolution $\mathrm{R}=50 \mathrm{eV}$, and with 256 recording channels. The XPS recorded spectra were processed using Spectral Data Processor v2.3 (SDP) software.

\section{$X$-ray diffraction $(X R D)$}

The samples were characterized for phase content by Xray diffraction (XRD) with a Bruker D8-Advance X-ray diffractometer in the scanning range $10-60^{\circ}$ using $\mathrm{CuK}_{\alpha 1}$ (1.5416 ̊̊) incident radiation.

\section{Scanning electron microscope (SEM) coupled with an energy dispersive $X$-ray detector (EDX) and glow discharge optical emission spectroscopy}

The morphology of the material was studied using a HITACHI S2600N-type scanning electron microscope (SEM), operating at $25 \mathrm{kV}$ in vacuum on powder samples. The elemental local analysis was performed using an energy dispersive spectroscopy (EDS) detector from EDAX. Operating conditions were an accelerating voltage between 2 up $25 \mathrm{kEv}$ (depending of the ratio signal/noise) with samples tilted at $25^{\circ}$ to get the optimal take off angle $\left(30^{\circ}\right)$ allowing a dead time around $20-30 \%$ and a collecting time of 90-120 s. The nature of the sample avoids a conductive thin film deposition previously.

The top surface analysis of the samples was studied by the Glow Discharge Optical Emission Spectroscopy (GDOES) using the GD5000 from Horiba/Jobin-Yvon. The technique is dedicated for thin film analysis and helps in determining the chemical gradient composition from the surface to the bulk and -if the ablation rate can be estimated - to precise the thickness of the different layers of the nanocomposite materials [29].

\section{Fourier transform infrared (FTIR) spectroscopy}

The functional groups present in the prepared nanoparticles and thin films were identified by FTIR using a Spectrum BX spectrometer. To obtain the nanoparticles spectra $1 \%$ of nano-powder was mixed and ground with $99 \% \mathrm{KBr}$. Tablets of $10 \mathrm{~mm}$ diameter were prepared by pressing the powder mixture at a load of 5 tons for 2 min. The spectrum was taken in the range of 500 to $4000 \mathrm{~cm}^{-1}$ with $4 \mathrm{~cm}^{-1}$ resolution. All the second derivative IR spectra were obtained after 49 -point smoothing of the original IR spectra at room temperature.

\section{Cell culture and treatment}

Human liver hepatocellular carcinoma, Hep G2 cells were maintained in minimal essential medium (MEM) containing 3,7 g/L sodium bicarbonate, 4,5 g/L D-glucose, 4,7 g/L 4-(2-hydroxyethyl)-1-piperazineethanesulfonic acid (HEPES), $4 \mathrm{mM}$ L-glutamine, $0,1 \mathrm{mM}$ sodium pyruvate, $100 \mathrm{U} / \mathrm{ml}$ penicillin, $100 \mathrm{U} / \mathrm{ml}$ streptomycin and $10 \%(\mathrm{v} / \mathrm{v})$ foetal bovine serum. Cells were grown in $5 \% \mathrm{CO}_{2}$ at $37^{\circ} \mathrm{C}$, as monolayers in $75 \mathrm{~cm}^{2}$ cell culture flasks. Then, HepG2 cells were seeded in six well plates, at a density of $5 \times 10^{5}$ cells $/ \mathrm{ml}$ and incubated on previously UV sterilized thin films of dextran nanoparticles as well as dextran coated maghemite $\gamma-\mathrm{Fe}_{2} \mathrm{O}_{3}$ nanoparticles obtained from composite targets containing 1\% (B) and $5 \%(\mathrm{C})$ maghemite $\gamma-\mathrm{Fe}_{2} \mathrm{O}_{3}$.

\section{Analysis of the actin cytoskeleton}

The Hep G2 cells were incubated on the three types of thin films for 24 and $72 \mathrm{~h}$. After the removal of the cell medium, the cells were washed by $70 \%$ cold methanol for 15 minutes on shaking. After three washes with phosphate buffer saline, $500 \mu \mathrm{l} / \mathrm{mL}$ of $20 \mu \mathrm{g} / \mathrm{mL}$ phaloidin coupled with FITC (fluorescein -isothiocyanate) in $1.2 \%$ bovine serum albumin on each thin film were added. After 1.5 hours of incubation in dark, this reagent was removed and three washes with phosphate buffer saline (five minutes each) were done. Then 500 $\mu \mathrm{L}$ of $10 \mu \mathrm{g} / \mathrm{ml}$ DAPI (4'-6-Diamino-2-phenylindole) were added for 15 minutes in order to stain the nuclei. The cells were analysed using Olympus IX71 microscope with an excitation wavelength of $495 \mathrm{~nm}$ and an emission of $513 \mathrm{~nm}$ for FITC and $358 \mathrm{~nm}$ respectively $461 \mathrm{~nm}$ for DAPI.

\section{Results and discussions}

Few studies were reported on the formation of dextran coated iron oxide thin films using MAPLE technique.

The XRD peaks of iron oxide nanoparticles (Figure 1A) and dextran coated iron oxide nanoparticles thin films (Figure 1B and 1C) can be indexed into the spinel cubic lattice type (ICSD card no.01-083-0112) with a lattice parameter of $8.36 \AA$. Diffraction peaks at (111), (220), (311), (400), (422), (511) and (440) are readily recognized from the XRD pattern in the iron oxide powders. The refinement of XRD spectra indicated that no other phases except the maghemite are detectable. The XRD showed a finite broadening of the diffraction lines. The particle sized calculated using the Scherer 


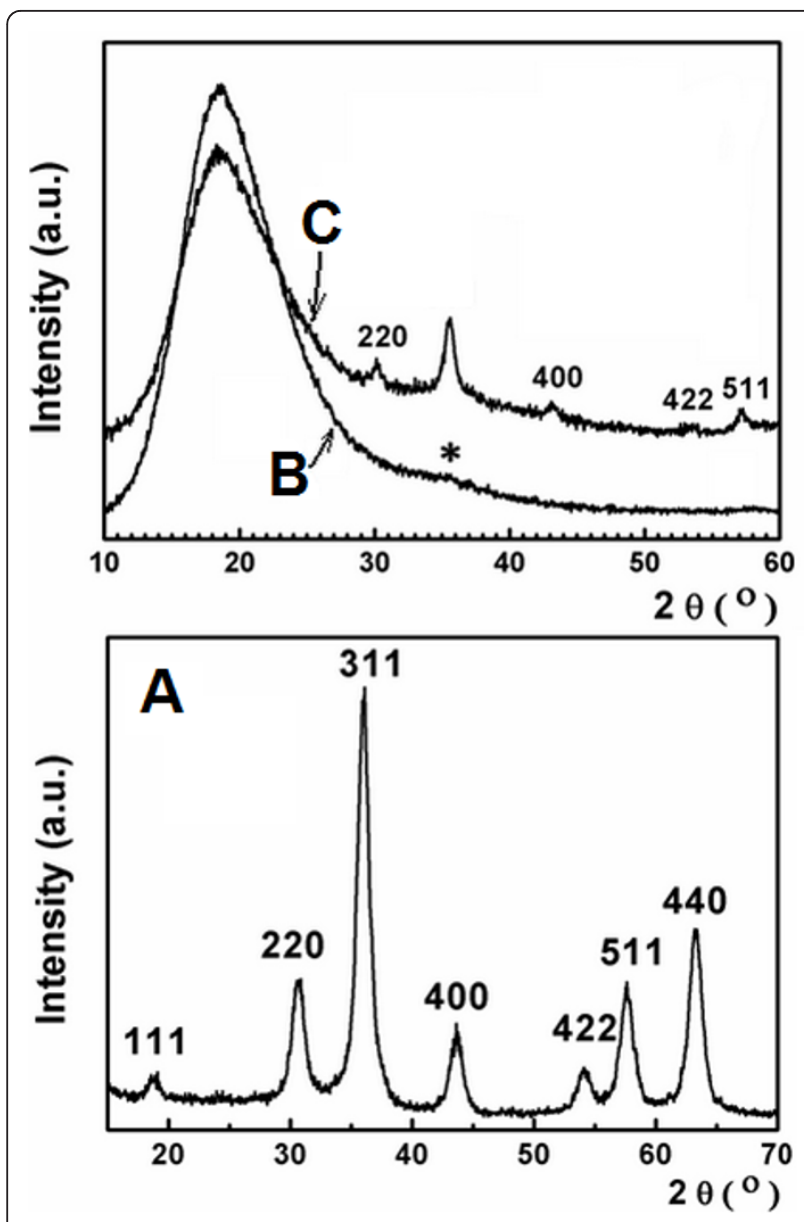

Figure 1 XRD patterns of dextran coated maghemite $\gamma-\mathrm{Fe}_{2} \mathrm{O}_{3}$ nanoparticles (A), thin films of dextran coated maghemite nanoparticles obtained from composite targets containing 1 wt.\% (B) and 5 wt.\% (C) maghemite $\gamma-\mathrm{Fe}_{2} \mathrm{O}_{3}$.

[30] formula was estimated at around $7.7 \mathrm{~nm}$. The DRX analyses (Figure $1(\mathrm{~B}-\mathrm{C})$ ) show that the structure of the thin solid films of dextran coated maghemite nanoparticles obtained from composite targets containing 1 wt.\% (B) and 5 wt.\% (C) maghemite $\gamma-\mathrm{Fe}_{2} \mathrm{O}_{3}$ are monophase maghemite $\gamma-\mathrm{Fe}_{2} \mathrm{O}_{3}$ with different particle size and different degree of crystallinity.

X-ray photoelectron spectroscopy (Figure 2) and X-ray diffraction (Figure 1) results are consistent with the expected composition of dextran coated maghemite $\gamma$ $\mathrm{Fe}_{2} \mathrm{O}_{3}$ thin films. In the XPS general spectra of dextran thin film Figure 2(A) the binding energy of $\mathrm{O}(1 \mathrm{~s}$, $532.55 \mathrm{eV})$ and $\mathrm{C}(1 \mathrm{~s}, 286.43 \mathrm{eV})$ were found. The XPS shows that the binding energy of the $\mathrm{Fe} 2 \mathrm{p}_{3 / 2}$ of two thin films of dextran coated iron oxide (Figure 2(B-C)) is consistent with $\mathrm{Fe}^{3+}$ oxides.

In addition existence of doublet spin orbit component corresponding to $\mathrm{Fe} 2 \mathrm{p}_{3 / 2}$ and $\mathrm{Fe} 2 \mathrm{p}_{1 / 2}$ is presented in the spectra of the thin solid films of dextran coated

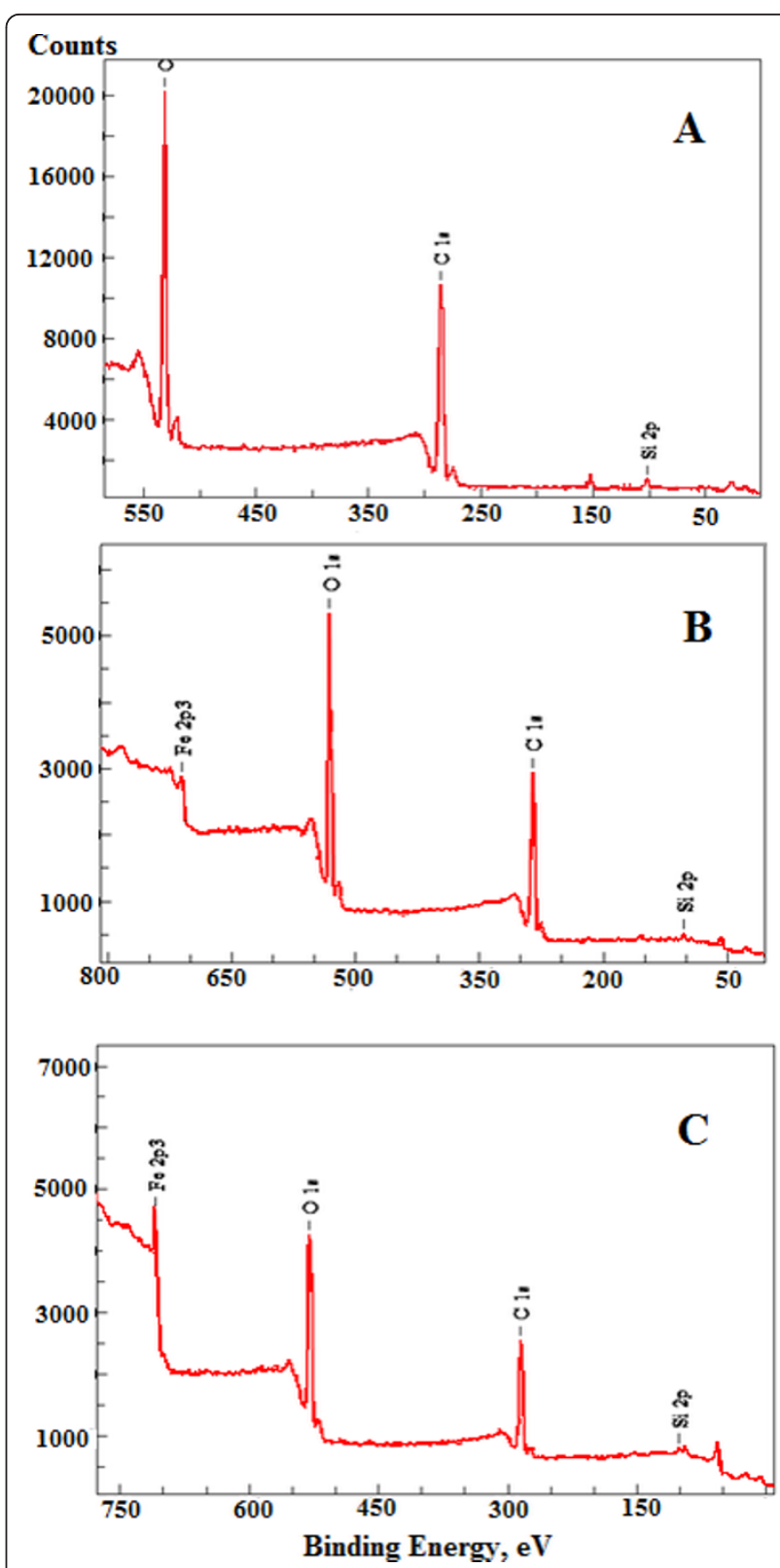

Figure 2 XPS spectrum of dextran thin film (A) and thin films of dextran coated maghemite nanoparticles obtained from composite targets containing 1 wt.\% (B) and 5 wt.\% (C) maghemite $\gamma-\mathrm{Fe}_{2} \mathrm{O}_{3}$

maghemite nanoparticles obtained from composite targets containing $1 \mathrm{wt} . \%$ (Figure 3A) and 5 wt.\% (Figure $3 \mathrm{~B})$. The $\mathrm{Fe} 2 \mathrm{p}_{3 / 2}$ peak was found to have binding energy between energy $711.2 \mathrm{eV}$ and $711.6 \mathrm{eV}$ and the Fe $2 \mathrm{p}_{1 / 2}$ peak from 725.2 to $725.8 \mathrm{eV}$. The results indicate that iron was completely in the $\mathrm{Fe}^{3+}$ state. This result is also supported by the XRD results which indicate that $\gamma-\mathrm{Fe}_{2} \mathrm{O}_{3}$ phase contains only $\mathrm{Fe}^{3+}$ cations.

The broadened shape of the O 1 s spectra (Figure 4) suggests that the oxygen is present in at least two states. 

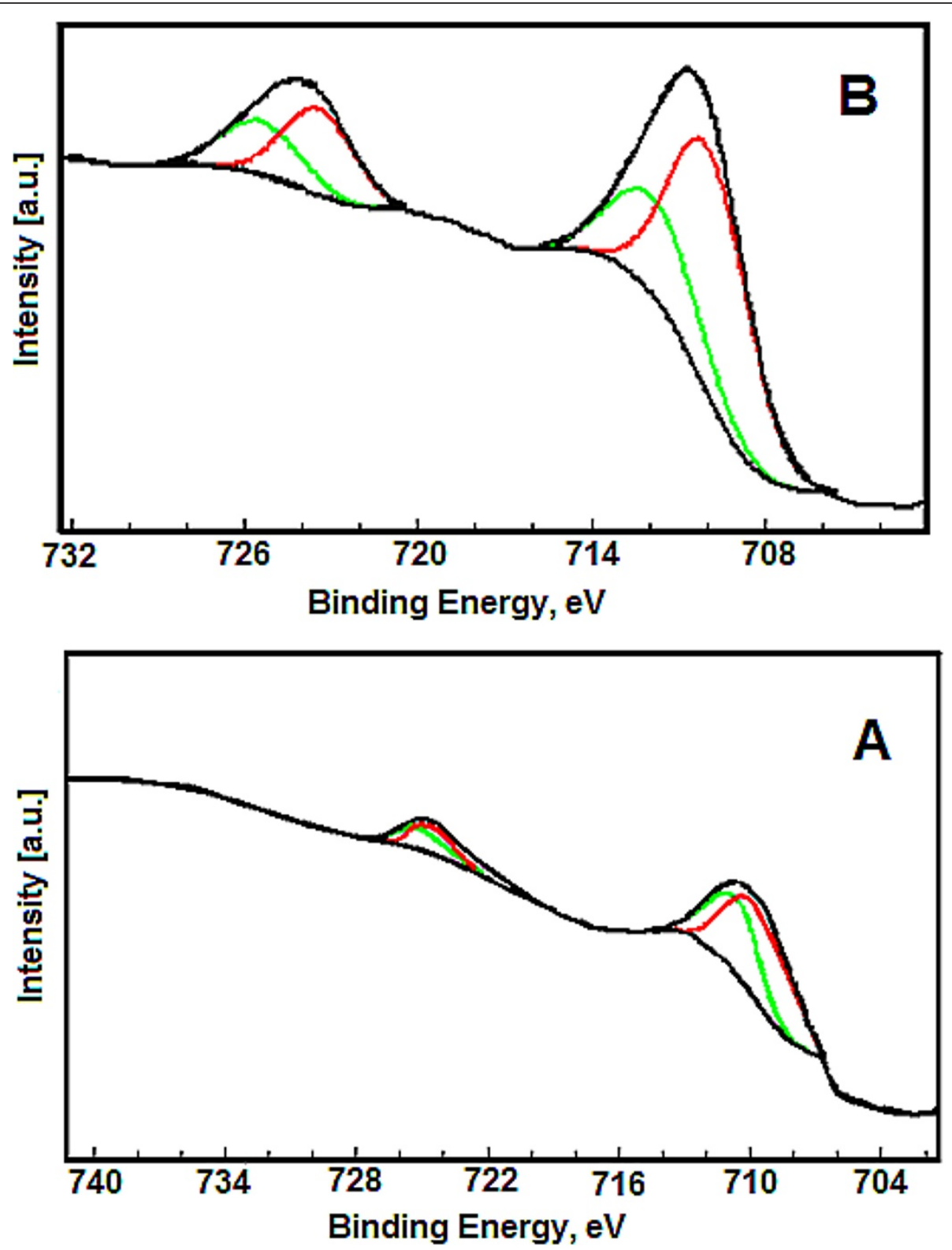

Figure 3 Fe $2 p$ XPS spectra for the thin solid films of dextran coated maghemite nanoparticles obtained from composite targets containing $1 \mathrm{wt} . \%$ (A) and $5 \mathrm{wt} . \%$ (B). The spectra were normalized to maximum intensity.

Figure 4 showed a typical O 1 spectrum fitted with two Gaussian components. The binding energy separation is $2.31 \mathrm{eV}$ in good accord with literature [31]. The main peak is located at $530.58 \mathrm{eV}$. This component corresponds to $\mathrm{O}^{2-}$ in the iron oxide lattice $[32,33]$. The second component is represented by a peak located at $532.89 \mathrm{eV}$ and could be attributed to $\mathrm{OH}^{-}$[34-38] and physisorbed $\mathrm{H}_{2} \mathrm{O}$, respectively. On the other hand, the $\mathrm{O} 1 \mathrm{~s}$ photoelectrons in both thin films of dextran coated maghemite are due to dextran (C-O-C [or H]) contributions [39].

The major components of the $\mathrm{C} 1 \mathrm{~s}$ at 286,3 eV (Figure 4 ) in the spectra of thin films of dextran coated maghemite $\gamma-\mathrm{Fe}_{2} \mathrm{O}_{3}$ are due primarily to the dextran $\mathrm{CHOH}$ groups. A smaler peak at $\sim 288 \mathrm{eV}$ is assigned to the anomeric carbon of dextran. The components of the $\mathrm{Si} 2 \mathrm{p}$ in all spectra are due to the substrate contributions.

The GDOES Spectra respectively performed on thin films of dextran coated maghemite nanoparticles are obtained from composite targets containing 1 wt.\% (A) and 5 wt.\% (B) maghemite $\gamma-\mathrm{Fe}_{2} \mathrm{O}_{3}$ deposited on a silica glass substrate. The two spectra (Figure 5A and 5B) reveal the presence of a material composed mainly of carbon, iron and oxygen. Top surface (before 10s of 


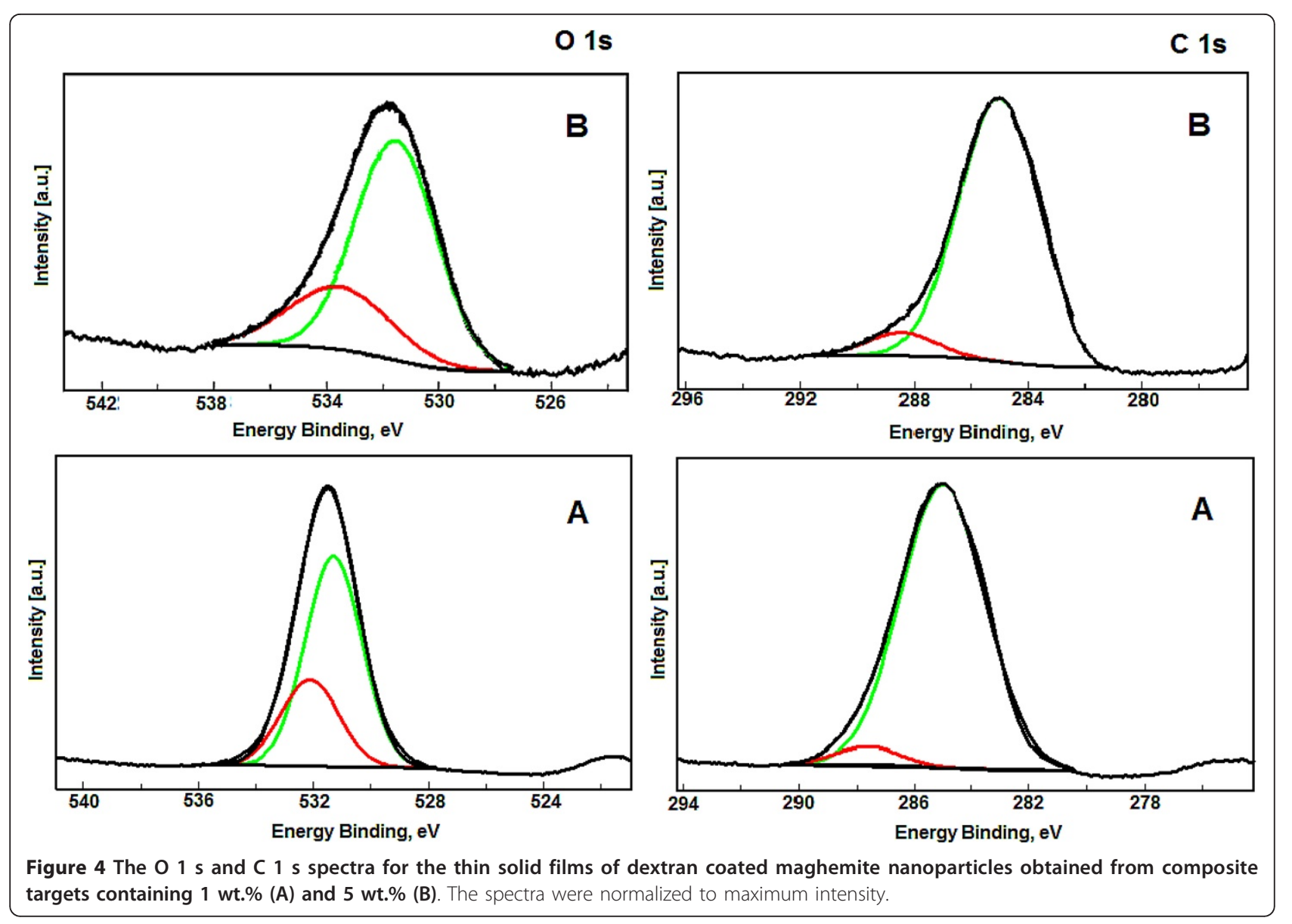

analytical time) corresponds to a contaminated layer (carbon oxygen mainly) frequently observed in as received material [29]. Between 10s and $180 \mathrm{~s}$ (Figure $5 \mathrm{~A}$ ) or $140 \mathrm{~s}$ (Figure $5 \mathrm{~B}$ ), carbon, iron and oxygen signals increased to reach a maximum before decreasing. This zone corresponds to the nanocomposite of dextran spiked with maghemite $\gamma-\mathrm{Fe}_{2} \mathrm{O}_{3}$. After $180 \mathrm{~s}$ or $140 \mathrm{~s}$, the signal of silicon increases corresponding to the glass substrate. Thus the signal observed between $10 \mathrm{~s}$ and respectively $180 \mathrm{~s}$ for $\mathrm{A}$ and $140 \mathrm{~s}$ for $\mathrm{B}$, exhibit the same pattern differing only by the intensity measured. In the case of the $1 \%$ sample (A) the iron signal is lower than carbon which is opposite with the sample doped by $5 \%$ of iron (B). The carbon signal corresponds to the dextran while iron is related to the maghemite. However, oxygen is included in both phases. Thus the
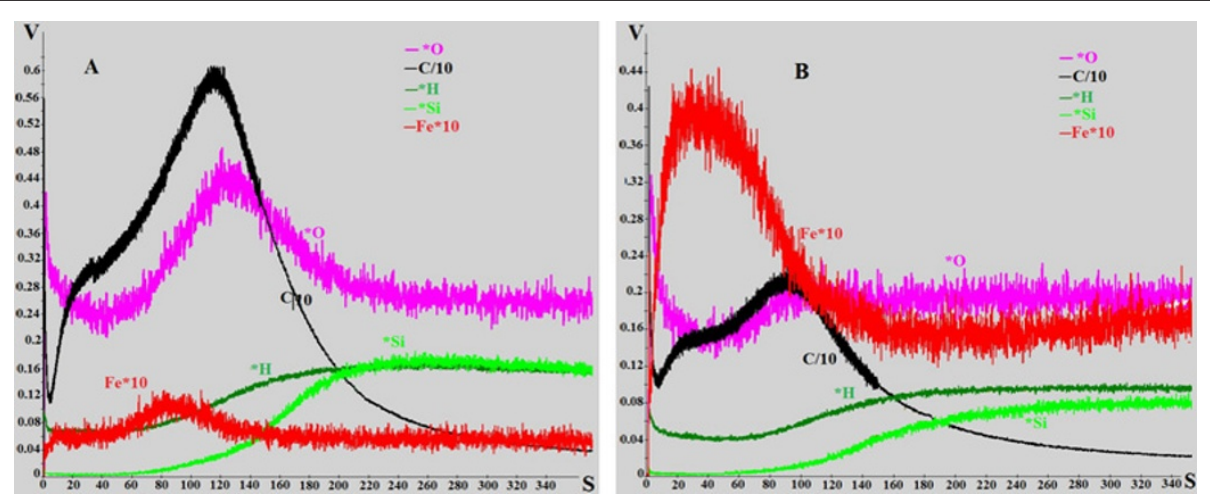

Figure 5 Analytical results by GDOES on thin films of dextran coated maghemite nanoparticles obtained from composite targets containing 1 wt.\% (A) and 5 wt.\% (B) maghemite $\gamma-\mathrm{Fe}_{2} \mathrm{O}_{3}$. 
sequences observed on the Figure 5 tends to reveal that maghemite is embedded by the dextran regardless the concentration. Average rate of ablation was around 2s/ min. By measuring the depth of the GD crater using profilometry, the thin film thickness was estimated about $280 \mathrm{~nm}$ (sample B) and $360 \mathrm{~nm}$ (sample A).

In Figure 6A, B and 6C are showed SEM micrographs (magnification 10000) of surface morphology for thin films of dextran (A) and thin films of dextran coated maghemite nanoparticles obtained from composite targets containing $1 \mathrm{wt} . \%$ (B) and 5 wt.\% (C) maghemite. SEM images provide the direct information about the size and typical shape of the as prepared samples. The SEM observations for the thin film of maghemite-dextran showed that the samples consist of regular grains with some aggregation. Additionally, the grain size increased when the concentration of the maghemite NPs increased from $1 \mathrm{wt}$ \% (Figure 6(B)) to $5 \mathrm{wt} . \%$ (Figure $6(C)$ ). Surface SEM observation of thin films investigated show a granular structure with grain having an average particles dimensions ranging in the $40-150 \mathrm{~nm}$ for composite targets containing $1 \mathrm{wt} . \%$ maghemite and 60-200 $\mathrm{nm}$ for composite targets containing $5 \mathrm{wt} \%$ maghemite. EDAX (Figure 7) images of thin films of dextran and thin films of dextran coated maghemite nanoparticles obtained from composite targets containing 1 wt.\% (B) and 5 wt.\% (C) maghemite are shown. Elemental maps (Figure 7) of $\mathrm{C}, \mathrm{O}$ and $\mathrm{Fe}$ for the samples prepared from composite targets containing $1 \mathrm{wt} \%$ (B) and 5 wt.\% (C) $\gamma-\mathrm{Fe}_{2} \mathrm{O}_{3}$ are also shown. X-EDS spectra from the specimen confirm the composition of thin films samples. The carbon $(\mathrm{C})$, oxygen $(\mathrm{O})$ and iron $(\mathrm{Fe})$ contents of the films were measured by X-EDS. The atomic percentage of the $\mathrm{C}, \mathrm{O}$ and $\mathrm{Fe}$ are 66.71, 32.76 and 0.53 for the films deposited from composite targets containing $1 \mathrm{wt} . \%$ maghemite and 64.36, 33.92 and 1.72 respectively for the films deposited from composite targets containing $5 \mathrm{wt} . \%$ maghemite.

FT-IR is one of the most widely used methods to identify the chemical constituents and elucidate the compounds structures. IR spectrum of all thin films shows lot of structural information of major constituents. As shown in Figure 8 in the $3600-1600 \mathrm{~cm}^{-1}$ region four bands appear: a broad band centered at $3400 \mathrm{~cm}^{-1}$ and $1700 \mathrm{~cm}^{-1}$ assigned to the $\mathrm{OH}$ stretching $(\mathrm{vOH})$ and $\mathrm{HOH}(\mathrm{\delta OH})$ vibrational bands due to the adsorbed water molecules in the sample [40], the weak signal at $2927 \mathrm{~cm}^{-1}$ [41-43]. The band at $1434 \mathrm{~cm}^{-1}$ may by due to $\mathrm{C}-\mathrm{OH}$ deformation vibration with contributions of $\mathrm{O}-\mathrm{C}-\mathrm{O}$ symetric stretching vibration of carboxylate group $[44,45]$. The stronger peaks appear in the range of $1150-900 \mathrm{~cm}^{-1}$ mainly attributed to the stretching vibration of C-O-C [46]. Those characters of peaks intensities and positions at 1150, 1020, 912 and 731 in
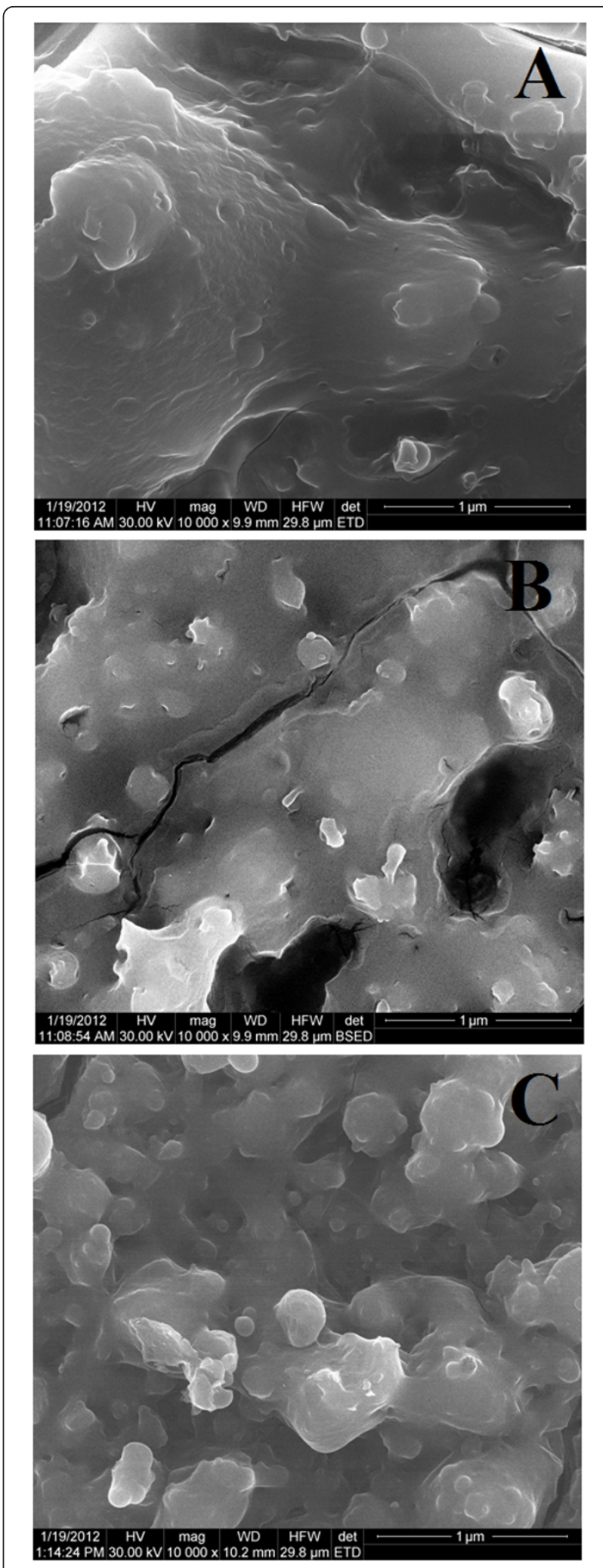

Figure 6 SEM micrographs of dextran thin films (A) and thin films of dextran coated maghemite nanoparticles obtained from composite targets containing 1 wt.\% (B) and 5 wt.\% (C) maghemite. 

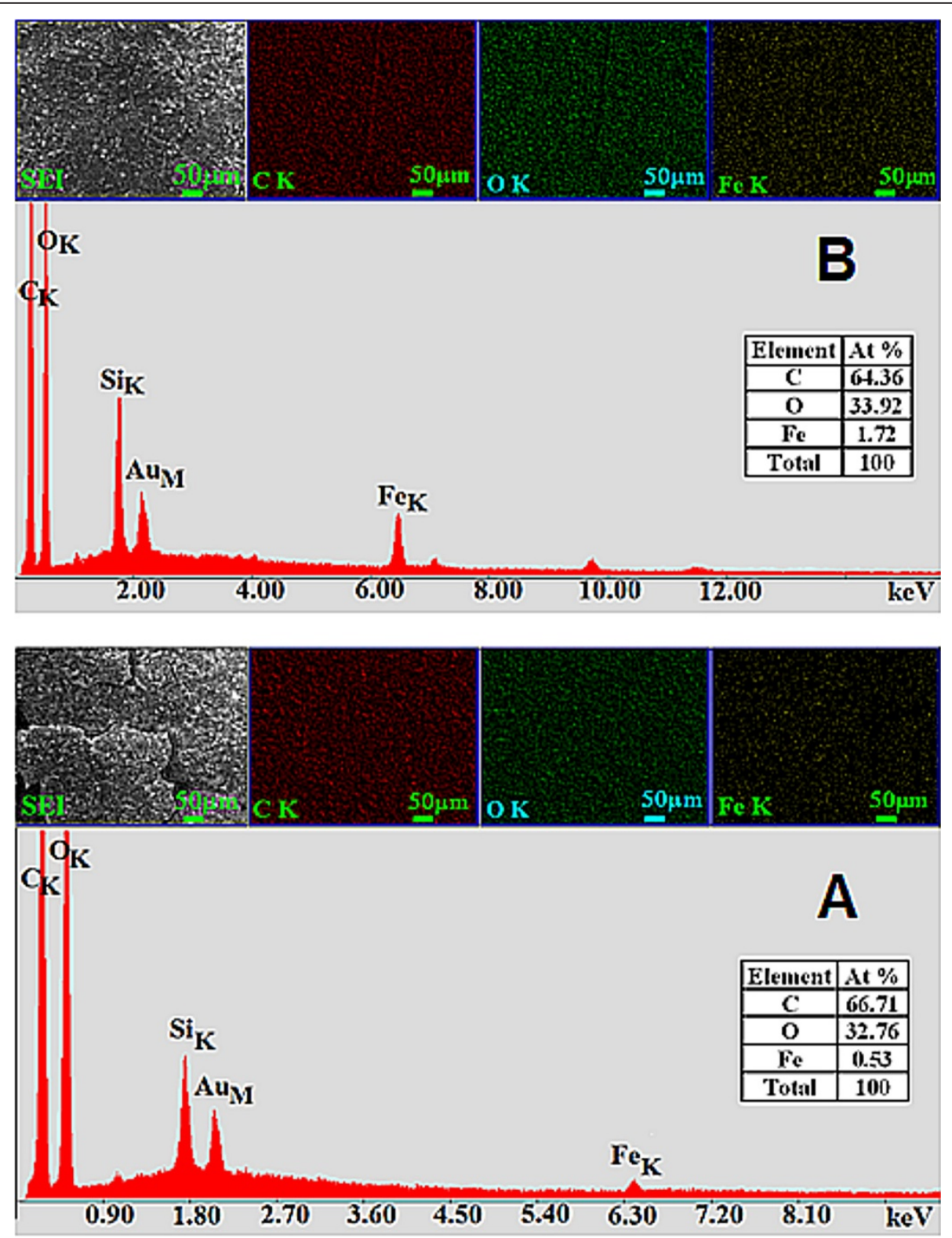

Figure 7 EDAX spectrum of thin films of dextran coated maghemite nanoparticles obtained from composite targets containing 1 wt. $\%$ (A) and 5 wt.\% (B) maghemite and simultaneous distributions of individual elements based on selected region of the sample.

the IR spectrum display the characteristic absorptions of polysaccharides. The bands observed in the $650-550 \mathrm{~cm}^{-}$ ${ }^{1}$ corresponds to the Fe-O vibrations modes of $\gamma-\mathrm{Fe}_{2} \mathrm{O}_{3}$ [47-52]. The FT-IR spectra and the second derivative spectra gives more information than classical IR for polysaccharides and other biomolecules contained in different organism such as red seaweeds, fungi and bacteria [53-57]. Furthermore, in the second derivative spectrum the bands observed are assigned to polysaccharides.

Our previous data proved a good viability of Hep G2 cells grown on dextran powder [58] as well as dextran coated maghemite thin films [59]. Also, no changes in cells morphology were noticed under phase contrast microscopy [60]. In this study, we were interested in the expression of F-actin in Hep G2 cells adhered to dextran nanoparticles and dextran coated maghemite $\gamma$ $\mathrm{Fe}_{2} \mathrm{O}_{3}$ nanoparticles obtained from composite targets containing 1 wt.\% and 5 wt. $\%$ maghemite $\gamma-\mathrm{Fe}_{2} \mathrm{O}_{3}$ thin films. Actins are highly conserved proteins that are ubiquitously expressed in all eukaryotic cells. F-actin microfilaments are essential for the maintenance of cell shape and permeability of tight junctions [61]. Figure 9 shows that, after 24 hours of cultivation, the expression of Factin in Hep G2 cells adhered on dextran nanoparticles 


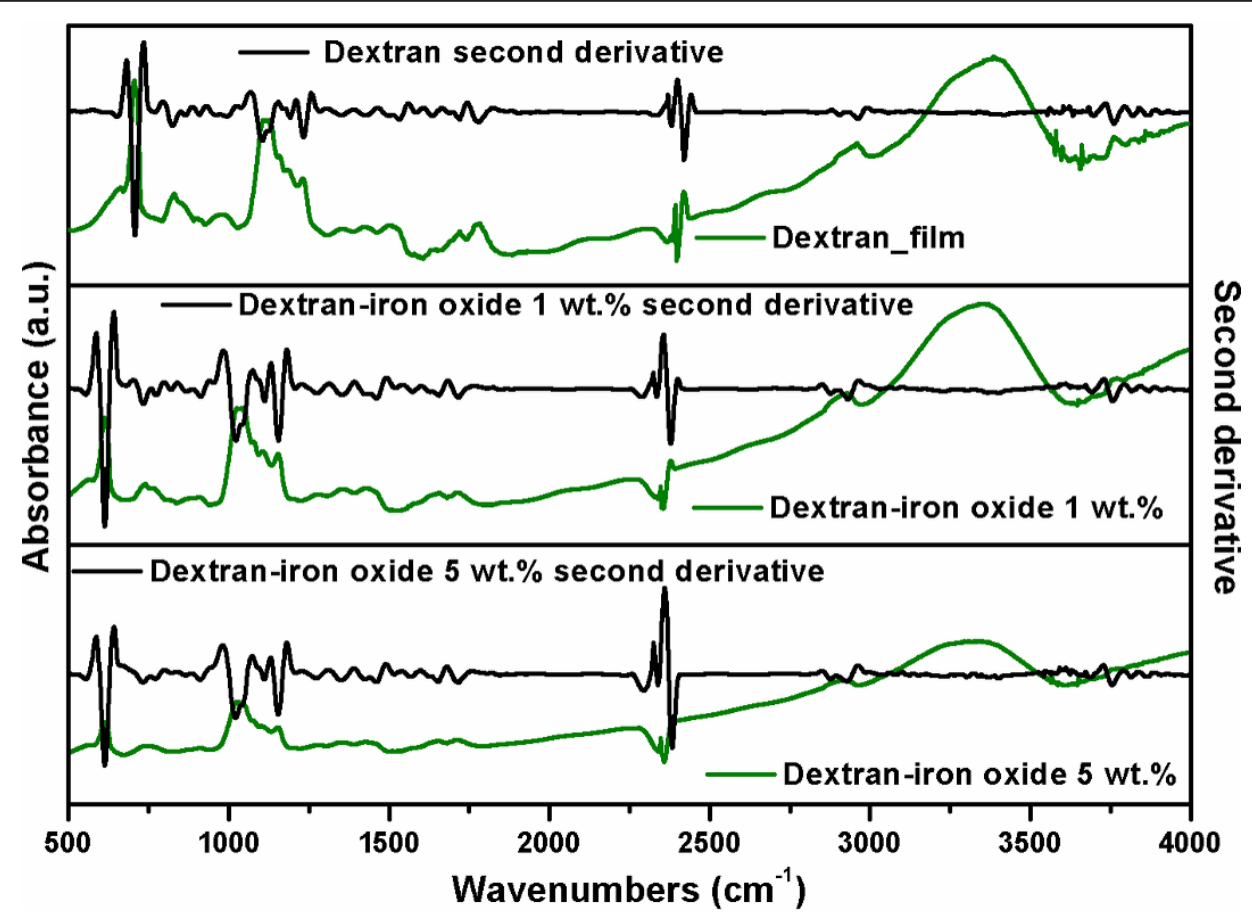

Figure 8 FT-IR spectra (green) and second derivative (black) of thin film of dextran nanoparticles, as well as thin films of dextran coated maghemite $\gamma-\mathrm{Fe}_{2} \mathrm{O}_{3}$ nanoparticles obtained from composite targets containing 1 wt.\% and 5 wt.\% maghemite $\gamma$ - $\mathrm{Fe}_{2} \mathrm{O}_{3}$.
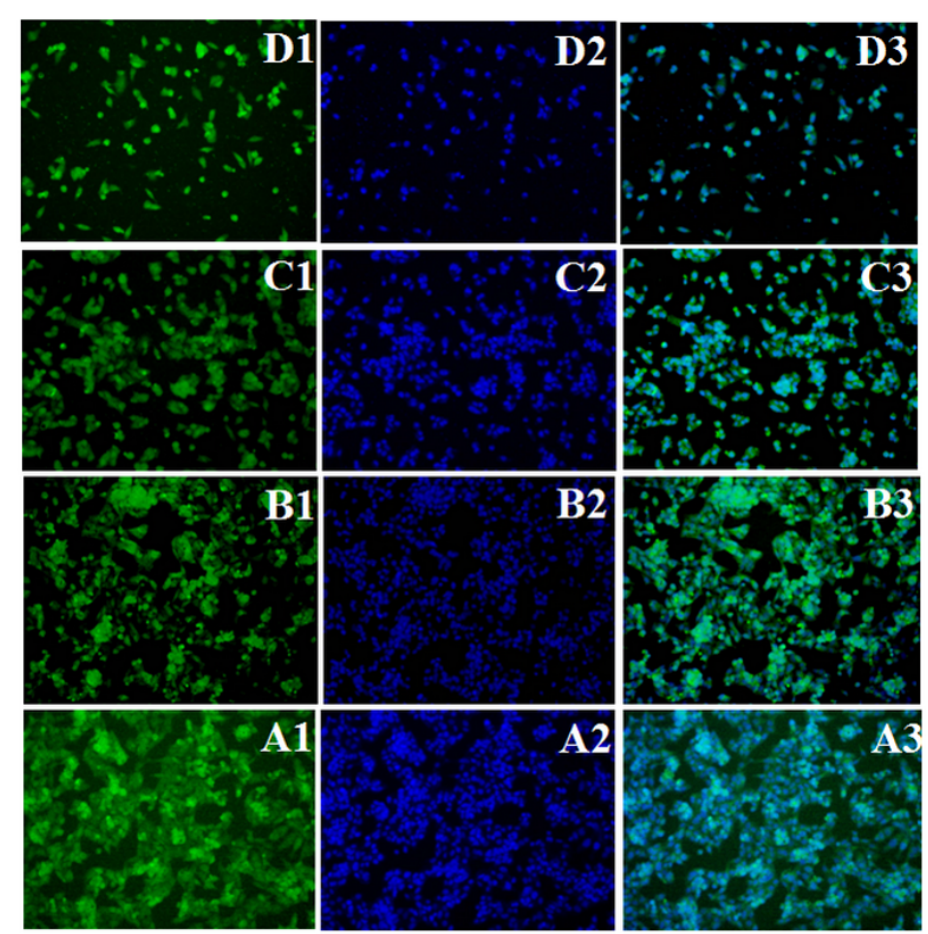

\section{4h F-actin}

DAPI

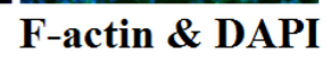

Figure 9 The localization of F-actin in HepG2 cells. The cells were cultured for $24 \mathrm{~h}$ stained first for F-actin with phalloidin (A1-control cells, B1-cells cultivated on thin films of dextran, C1-cells cultivated on thin films of dextran coated 1\% maghemite nanoparticles, D1-cells cultivated on thin films of dextran coated $5 \%$ maghemite nanoparticles), then incubated with DAPI for the detection of nuclei (A2, B2, C2, D2) and examined by fluorescence microscopy. A3, B3, C3, D3 images represent the previous images superimposed. The images shown are representative for five independent experiments. 

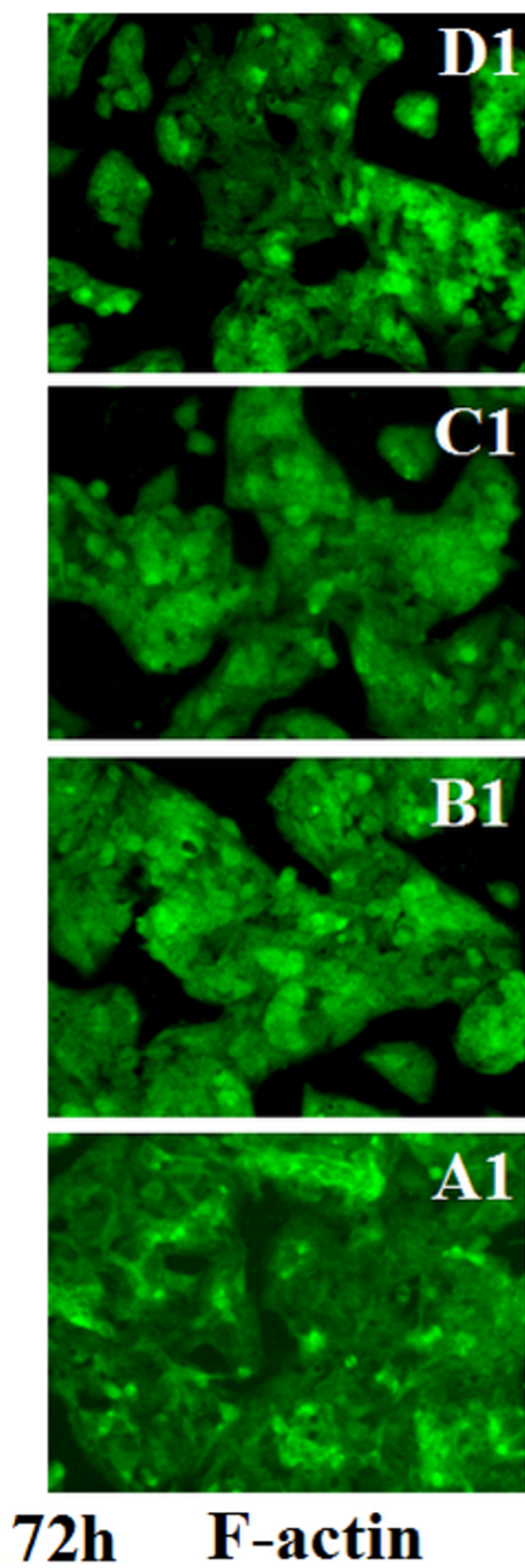
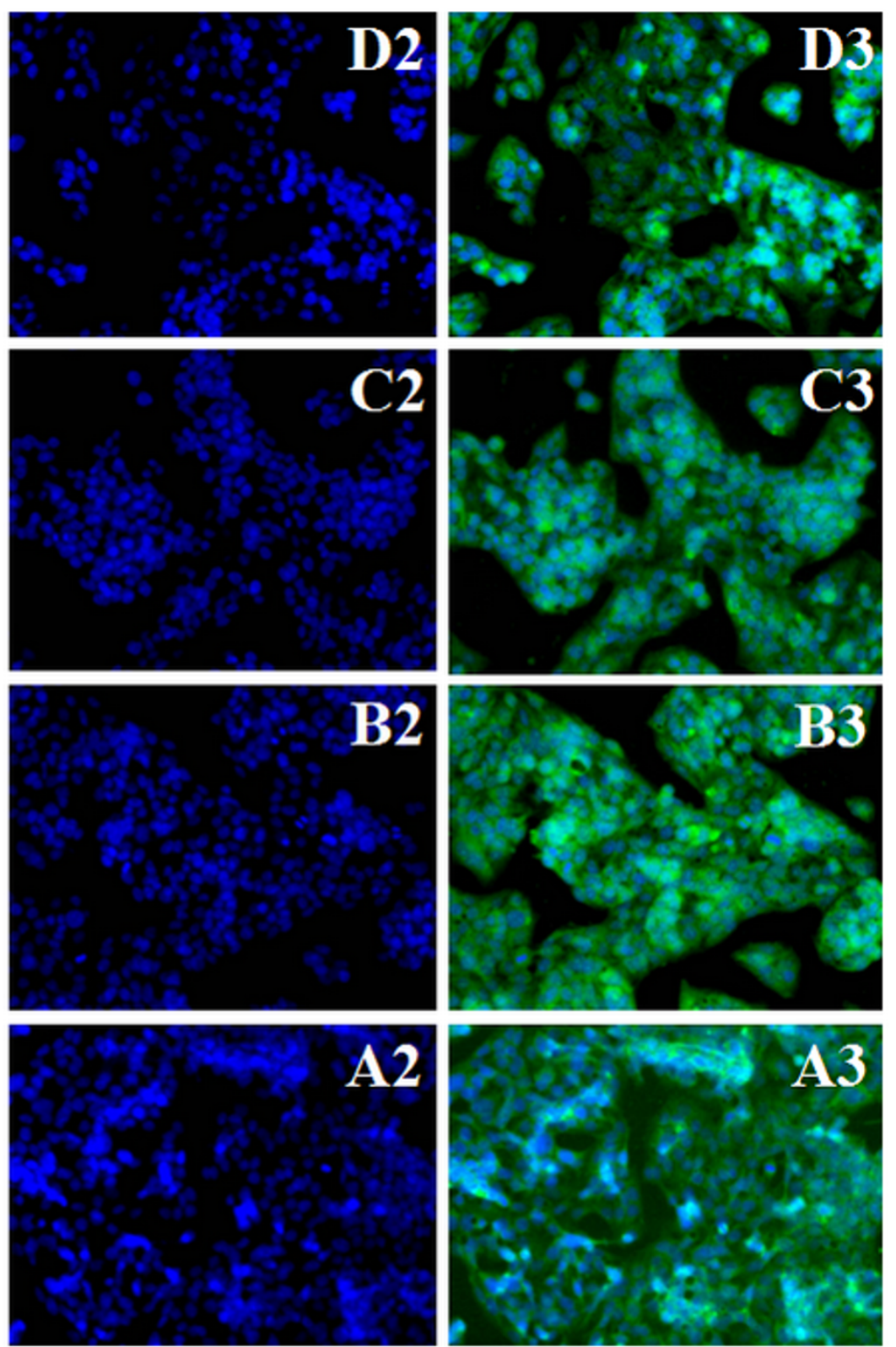

DAPI

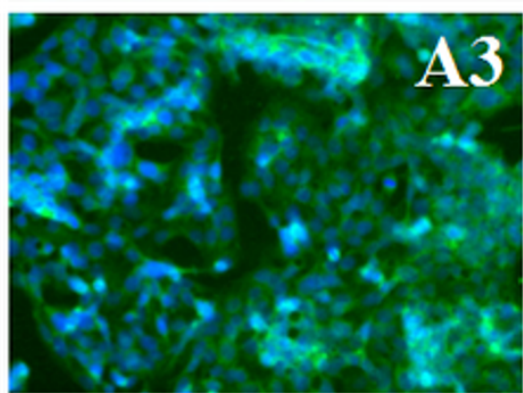

F-actin \& DAPI

Figure 10 The localization of F-actin in HepG2 cells. The cells were cultured for $72 \mathrm{~h}$ stained first for F-actin with phalloidin (A1-control cells, B1-cells cultivated on thin films of dextran, C1-cells cultivated on thin films of dextran coated 1\% maghemite nanoparticles, D1-cells cultivated on thin films of dextran coated $5 \%$ maghemite nanoparticles), then incubated with DAPI for the detection of nuclei (A2, B2, C2, D2) and examined by fluorescence microscopy. A3, B3, C3, D3 images represent the previous images superimposed. The images shown are representative for five independent experiments.

thin films (B) and dextran coated $1 \%$ maghemite $\gamma$ $\mathrm{Fe}_{2} \mathrm{O}_{3}(\mathrm{C})$ was similar and less than in control cells.

In the case of cells cultivated on dextran coated $5 \%$ maghemite $\gamma-\mathrm{Fe}_{2} \mathrm{O}_{3}$ (D1), the number of cells and the level of F-actin were lower compared to the other two types of thin films and control. After 24 hours, the Factin distribution in the cells from the thin films was especially around the nuclei. Later on, at 72 hours (Figure 10) after the cells cultivation there was no significant difference between the three experimental alternatives from the point of view of cell numbers and F-actin expression. It might be worthwhile to mention that F-actin is spread until the periphery of the hepatocytes, which is in accordance with other scientific results $[60,61]$. 


\section{Conclusions}

The dextran-iron oxide continuous thin films obtained by MAPLE technique from composite targets containing 10 wt.\% dextran as well as 1 and 5 wt.\% iron oxide nanoparticles synthesized by co-precipitation method presented granular surface morphology. This represented an advantage in the adhesion and growth of living HepG2 cells. Our results proved that Hep G2 cells adhered very well to thin films of dextran (coated with $1 \%$ and 5\% maghemite) and exhibited a normal actin cytoskeleton, which suggest that these cells underwent normal cell cycle progression. As a result, hepatocytes adhered to these thin films could be used as biosenzors for different xenobiotics.

\section{Acknowledgements}

This study was financially supported by Grant POSDRU 88/1.5/S/61150/2010 co-financed from European Social Fund by the Sectorial Operational Program for Development of Human Resources 2007-2010.

\section{Author details}

${ }^{1}$ National Institute of Materials Physics, P.O. Box MG 07, Bucharest, Magurele, Romania. ${ }^{2}$ CSIC-CIN2, Campus UAB, 08193 Bellaterra, Spain. ${ }^{3}$ Department of Biochemistry and Molecular Biology, University of Bucharest, 050095 Bucharest, Romania. ${ }^{4}$ Université Bordeaux 3, EA 4592G\&E, EGID, 1 allée Daguin, 33607, Pessac, Cedex, France. ${ }^{5}$ University of Dayton, 300 College Park, Dayton, OH 45469, USA.

\section{Authors' contributions}

$\mathrm{KL}, \mathrm{MC}$, and $\mathrm{AD}$ conceived the experiments. SLI synthesised the iron oxide ferofluid. CSC performed FT-IR and XPS studies. PLC performed structural studies. MR reported all biological experiments. DP wrote the manuscript. All the authors read and approved the manuscript.

\section{Competing interests}

The authors declare that they have no competing interests.

Received: 8 November 2011 Accepted: 13 March 2012

Published: 13 March 2012

\section{References}

1. Pardoe H, Chua-Anusorn W, St. Pierre TG, Dobson J: Structural and Magnetic Properties of Nanoscale Iron Oxide Particles Synthesized in the Presence of Dextran or Polyvinyl Alcohol. J Magn Magn Mater 2001, 225:41-46

2. Berry CC, Wells S, Charles S, Curtis ASG: Dextran and albumin derivatised iron oxide nanoparticles: influence on fibroblasts in vitro. Biomaterials 2003, 24:4551-4557.

3. Granick S: Physical and chemical properties of horse splcenferritin. J Biol Chem 1942, 146:451-461.

4. Bonnemain B: Superparamagnetic agents in magnetic resonance imaging: physiochemical characteristics and clinical applications-a review. J Drug Target 1998, 6:167-174.

5. Mornet S, Vasseur S, Garraset F, Duguet E: Magnetic nanoparticle design for medical diagnosis and therapy. J Mater Chem 2004, 14:2161-2175.

6. Huh YM, Jun YW, Song HT: In viv magnetic resonance detection of cancer by using multifunctional magnetic nanocrystals. J Am Chem Soc 2005, 127:12387-12391.

7. Johnson WK, Stoupis C, Torres GM, Rosenberg EB, Ros PR: Superparamagnetic iron oxide (SPIO) as an oral contrast agent in gastrointestinal (GI) magnetic resonance imaging (MRI): comparison with state-of-the-art computed tomography (CT). Magn Reson Imaging 1996, 14(1):43-49.

8. Dailey JP, Phillips JP, Li C, Riffle JS: Synthesis of silicone magnetic fluid for use in eye surgery. J Magn Magn Mater 1999, 194:140-148.
9. Jordan A, Schotz R, Wust P, Schirra H, Schiestel T, Schmidt H, Felix R: Endocytosis of dextran and silan-coated magnetite nanoparticles and the effect of intracellular hyperthermia on human mammary carcinoma cells in vitro. J Magn Magn Mater 1999, 194:185-196.

10. Jain TK, Morales MA, Sahoo SK, Leslie-Pelecky DL, Labhasetwar V: Iron-oxide nanoparticles for sustained delivery of anticancer agents. Mol Pharm 2005, 2:194-205.

11. Gupta AK, Gupta M: Synthesis and surface engineering of iron oxide nanoparticles for biomedical applications. Biomaterials 2005, 26:3995-4021.

12. Ito A, Kuga $Y$, Honda H, Kikkava H, Horiachi A, Watanabe $Y$, Kobayashi T: Magnetite nanoparticle-loaded anti-. HER2 immunoliposomes for combination of antibody therapy with hyperthermia. Cancer Lett 2004, 212:167-175.

13. Awsschalom DD, DiVincenza DP: Complex dynamics of meso-scopic magnets. Phys Today 1995, 48:43-48.

14. Prodan D, Chaneac C, Tronc E, Jolivet JP, Cherkaour R, Ezzir A, Nogues M, Dormann $J$ : Adsorption phenomena and magnetic properties of $\gamma-\mathrm{Fe}_{2} \mathrm{O}_{3}$ nanoparticles. J Magn Magn Mater 1999, 203:63-65.

15. Mornet $S$, Portier J, Duguet E: A method for synthesis and functionalization of ultrasmall superparamagnetic covalent carriers based on maghemite and dextran. J Magn Magn Mater 2005, 293:127-134.

16. Chan HT, Do YY, Huang PL, Chien PL, Chan TS, Liu RS, Huang CY, Yang SY, Horng HE: Preparation and properties of bio-compatible magnetic Fe3O4 nanoparticles. J Magn Magn Mater 2006, 304:415-417.

17. Berry CC, Curtis ASG: Functionalisation of magnetic nanoparticles for applications in biomedicine. J Phys D: Appl Phys 2003, 36:198-206.

18. Cristescu R, Stamatin I, Mihaiescu DE, Ghica C, Albulescu M, Mihailescu IN, Chrisey DB: Pulsed Laser Deposition of Biocompatible Polymers: a Comparative Study in Case of Pullulan. Thin Solid Films 2004, 453454:262-268

19. Smausz T, Megyeri G, Kékesi R, Vass C, György E, Sima F, Mihailescu IN, Hopp B: Comparative study on Pulsed Laser Deposition and Matrix Assisted Pulsed Laser Evaporation of urease thin films. Thin Solid Films 2009, 517:4299-4302.

20. Piqué A, McGill RA, Chrisey DB, Leonhardt D, Mslna TE, Spargo BJ, Callahan JH, Vachet RW, Chung R, Bucaro MA: Growth of organic thin films by the matrix assisted pulsed laser evaporation (MAPLE) technique. Thin Solid Films 1999, 355/356:536-541.

21. Wu PK, Ringeisen BR, Krizman DB, Frondoza CG, Brooks M, Bubb DM, Auyeung RCY, Piqué A, Spargo B, McGill RA, Chrisey DB: Laser transfer of biomaterials: Matrix-assisted pulsed laser evaporation (MAPLE) and MAPLE Direct Write. Rev Sci Instrum 2003, 74:2546-2557.

22. Jelinek M, Kocourek T, Remsa J, Cristescu R, Mihailescu IN, Chrisey DB: MAPLE Applications in Studying Organic Thin Films. Laser Phys 2007, 17:66.

23. Massart R: Magnetic fluids and process for obtaining them., US Patent 4329241, (1982).

24. Massart R: Preparation of aqueous magnetic liquids in alkaline and acidic media. IEEE Trans Magn 1981, 17:1247-1248.

25. Bee A, Massart R, Neveu S: Synthesis of very fine maghemite particles. J Magn Magn Mater 1995, 149(1-2):6-9.

26. Predoi $D$, Valsangiacom CM: Thermal studies of magnetic spinel iron oxide in solution. J Optoel Adv Mater 2007, 9:1797-1799.

27. Mornet S, Grasset F, Portier J, Duguet E: Maghemite@silica nanoparticles for biological applications. Eur Cell Mater 2002, 3S2:110.

28. Skoog DA, West DM, Holler FJ: Fundamentals of Analytical Chemistry. 7 edition. Fort Worth: Saunders college Publishing; 1996.

29. Le Coustumer P, Chapon P, Payling R, François Saint-Cyr H, Motelica Heino M: Surface characterization and depth profile analysis of glasses by r.f. GDOES. Surf Interface Anal 2003, 35:623-629.

30. Cornell RM, Schertmann U: Iron Oxides in the Laboratory: Preparation and Characterisation VCH:Weinheim; 1991.

31. Aronniemi M, Saino J, Lahtinen J: Characterization and gas-sensing behavior of an iron oxide thin film prepared by atomic layer deposition. Thin Solid Films 2008, 516:6110-6115.

32. Moses PR, Wier LM, Lennox IC, Finklea HO, Murray RW: X-ray photoelectron spectroscopy of alkylaminesilanes bound to metal oxide electrodes. Anal Chem 1978, 50:576-585.

33. Hendewerk M, Salmeron M, Somorjai GA: Water adsorption on the (001) plane of $\mathrm{Fe}_{2} \mathrm{O}_{3}$ : An XPS, UPS, Auger, and TPD study. Surf Sci 1986, 172:544-556 
34. Gaggiotti G, Galdikas A, Kačiulis S, Mattogno G, Setkus A: Surface chemical composition study of tin oxide based gas sensors. J Appl Phys 1994, 76:4467.

35. Kawabe T, Shimomura S, Karasuda T, Tabata K, Suzuki E, Yamaguchi Y: Photoemission study of dissociatively adsorbed methane on a preoxidized SnO2 thin film. Surf Sci 2000, 448:101-107.

36. Wandelt K: Photoemission Studies of Absorbed Oxygen and Ox- ide Layers. Surf Sci Rep 1982, 2:1-121.

37. Roosendaal SJ, Vredenberg AM, Habraken FHPM: Oxidation of Iron: The Relation between Oxidation Kinetics and Oxide Electronic Structure. Phys Rev Lett 2000, 84:3366-3369.

38. Desai JD, Pathan HM, Sun-Ki Min, Kwang-Deog Jung, Oh Shim Joo: FT-IR, XPS and PEC characterization of spray deposited hematite thin films. Appl Surf Sci 2005, 252:1870-1875.

39. Clarc DT: ESCA applied to organic and polymeric systems. In Hand Book of X-Ray and Ultraviolet Photoelectron Spectroscopy. Edited by: Briggs D. London: Heyden; 1977:220-222.

40. Bautista MC, Bomati-Miguel O, del Puerto Morales M, Serna CJ, Veintemillas Verdauguer S: Surface characterisation of dextran-coated iron oxide nanoparticles prepared by laser pyrolysis and coprecipitation. J Magn Magn Mater 2005, 293:20-27.

41. Wang HR, Chen KM: Preparation and surface active properties of biodegradable dextrin derivative surfactants. Colloids and Surfaces A: Physicochem Eng Aspects 2006, 281:190-193.

42. Castellanos Gil E, Colarte Al, El Ghzaoui A, Durand D, Delarbre JL, Bataille B: A sugar canenative dextran as innovative functional excipient for the development of pharmaceutical tablets. Eur J Pharm Biopharm 2008, 68:319-329.

43. Powers MJ, Rodriguez RE, Griffith LG: Cell-substratum adhesion strength as a determinant of hepatocyte aggregate morphology. Biotechnol Bioen 1996, 53:415-426.

44. Mathlouthi M, Koenig JL: Vibrational spectra of carbohydrates. Adv Carbohydr Chem Biochem 1986, 44:7-89.

45. Silverstein RM, Clayton Bassier G, Morrill TC: Spectrometric Identification of Organic Compounds New York: Wiley; 1991.

46. Lammers K, Arbuckle-keil G, Dighton J: FT-IR study of the changes in carbohydrate chemistry of three New Jersey pine barrens leaf litters during simulated control burning. Soil Biol Biochem 2009, 41:340-347.

47. Martin JLde Vidales, Lopez-Delgado A, Vila E, Lopez FA: The effect of the starting solution on the physico-chemical properties of zinc ferrite synthesized at low temperature. J Alloys Compd 1999, 287:276-283.

48. Predoi D: A study on iron oxide nanoparticles coated with dextrin obtained by coprecipitation. Dig J Nanomater Biostruct 2007, 2:169-173.

49. Hradil J, Pisarov A, Babič M, Horák D: Dextran-modified iron oxide nanoparticles. China Part 2007, 5:162-168.

50. Ciobanu CS, Pall L, Andronescu E, Iconaru SL, Gyorgy E, Predoi D: Physicochemical properties of iron-oxide-dextrin thin films. REV CHIM 2010, 61(12):1207-1211.

51. Vatasescu-Balcan RA, Predoi D, Costache M: Study of osteoblast interaction with iron oxide nanoparticles coated with dextrin in cell culture. FEBS J 2008, 275:374

52. Predoi D, Crisan O, Jitianu A, Valsangiacom MC, Raileanu M, Zaharescu M: Iron oxide in a silica matrix prepared by the sol-gel method. Thin Solid Films 2007, 16:6319-6323.

53. Caceres PJ, Faundez CA, Matsuhiro B, Vasquez JA: Carrageenophyte identification by secondderivate Fourier transform infrared spectroscopy. J Appl Phycol 1997, 8:523-527.

54. Michell AJ: Second-derivative FT-IR spectra of native celluloses. Carbohydr Res 1990, 173:185-195

55. Matsuhiro B: Vibrational spectroscopy of seaweed galactans. Hydrobiologia 1996, 326/327:481-489.

56. Matsuhiro B, Rivas P: Second-derivative Fourier transform infrared spectra of seaweed galactans. J Appl Phycol 1993, 5:45-51

57. Sandt G, Sockalingum GD, Aubert D, Lepan H, Lepouse C, Joussaud M, Leon A, Pinon JM, Manfait M, Toubas D: Use of fourier-transform infrared spectroscopy for typing of candida albicans strains isolated in intensive care units. J Clin Microbiol 2003, 41:954-959.

58. Oust A, Moretro T, Naterstad K, Sockalingum G, Adt I, Manfait M, Kohler A: Fourier transform infrared and Raman spectroscopy for characterization of Listeria mono-cytogenes strains. Appl Environ Microbiol 2006, 72:228-232.
59. Predoi D, Andronescu E, Radu M, Munteanu MC, Dinischiotu A: Synthesis and characterization of biocompatible maghemite nanoparticles. Digest $J$ Nanom Biostr 2010, 5:779-786.

60. Tsukada N, Ackerley CA, Philips MJ: The structure and organization of the bile canalicular cytoskeleton with special reference to actin and actinbinding proteins. Hepatology 1995, 21:1106-1113.

61. Wang YJ, Gregory RB, Barritt GJ: Regulation of F-actin and endoplasmic reticulum organization by the trimeric G-protein $\mathrm{Gi} 2$ in rat hepatocytes. Implication for the activation of store-operated $\mathrm{Ca} 2+$ inflow. J Biol Chem 2000, 275:22229-22237.

doi:10.1186/1752-153X-6-17

Cite this article as: Ciobanu et al.: Biomedical properties and preparation of iron oxide-dextran nanostructures by MAPLE technique. Chemistry Central Journal 2012 6:17.

Publish with ChemistryCentral and every
scientist can read your work free of charge
"Open access provides opportunities to our
colleagues in other parts of the globe, by allowing
anyone to view the content free of charge."
W. Jeffery Hurst, The Hershey Company.
- available free of charge to the entire scientific community
- cited in PubMed and archived on PubMed Central
- yours - you keep the copyright
Submit your manuscript here:
http://www.chemistrycentral.com/manuscript/

